\author{
Muldagaliyeva A.A. ${ }^{1}$, Okusheva G.T. ${ }^{2}$, Orazbekova I.G. ${ }^{3}$, \\ ${ }^{1,2}$ Candidate of Philological Sciences, Associate Professor, \\ ${ }^{3}$ Candidate of Philological Sciences \\ of Al-Farabi Kazakh National University, Kazakhstan, Almaty, \\ e-mail: aizhan.m@gmail.com,gulnarok.kz@gmail.com,indiragazizovna@mail.ru
}

\title{
SOCIOCULTURAL FUNCTIONS OF KAZAKH AFFINAL KINSHIP TERMS
}

The paper considers various aspects of kinship studies, namely, why and for what reasons the kinship systems have evolved and why they were so important, new kinship theories, incest taboo, terms of kinship, affinal kinship terms and the code of conduct to be maintained among affinal relatives. Kinship in human societies have evolved as a powerful mechanism for coordination, cooperation and as a resolution to conflict and tension connected with resource access. Incest taboo is an inalienable topic in kinship studies, which is also a strong mechanism ensuring the reproduction of healthy offspring and preservation of sound gene pool. Lately the changes taking place in societies gave rise to new conceptualization of families and kinship relations. One interesting topic, which the paper considers, is Kazakh affinal kinship and the code of conduct of each relative. The system of Kazakh kinship terms is very ramified and difficult for other peoples to understand, especially the terms of kinship by marriage. The study of this layer of vocabulary is relevant, since kinship in the Kazakh society plays an important role, and the traditions of behavior between relatives have not undergone significant changes.

Key words: kinship terms, code of conduct, marital relation, taboo, customs and traditions, affinal relations.

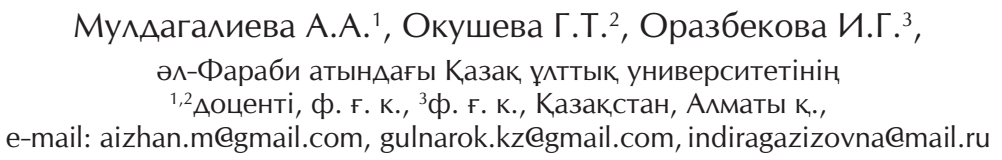

\section{Қазақтың неке туыстық терминдерінің әлеуметтік-мәдениеттік функциямары}

Мақалада туыстық қарым-қатынастарды зерттеулердің әртүрлі аспектілері талқыланады, атап айтқанда: туыстық жүйенің дамуында қандай себептер орын алды және неге ол аАамдар мен қоғам үшін маңызды болды, туыстық қарым-қатынастарды зерттеулерінің жаңа теориялары, инсест-табу, туыстық терминдер және мінез-құлық, кодексі. Тарихи дамуы кезінде адамзат қоғамында туыстық қатынастар бірлестікті, ынтымақтастықты және ресурстарға қол жеткізумен байланысты жанжа^дар мен шиеленістерді шешуді қамтамасыз ететін күшті механизм болды. Инсестке тыйым салу - бұл дені сау ұрпақты өмірге әкелу, сондай-ақ, салауатты гендік қорды сақтаудың қуатты механизмі болып табылады. Қазіргі кездегі қоғамда болып жатқан өзгерістерге байланысты отбасылар мен туыстық қарым-қатынастарды зерттеудің жаңа концепциялары пайда болуда. Осы мақалада қарастырылатын тағы да бір қызықты тақырып - қазақстандық туыстық аффиналдық жүйесі және ішкі тәртіп кодексі. Қазақтар арасындағы туыстық қатынастар жүйесі өте тармақталған және басқа халықтар үшін, әсіресе неке арқылы туыстық терминдерін және қарым-қатынас заңдылықтарын шетел студенттеріне түсіну қиын. Осыған байланысты лексиканың бұл тобын зерттеу өзекті болып табылады, өйткені қазақ қоғамында туыстық қарымқатынастар әлі де маңызды рөл атқарады және туыстар арасындағы мінез-құлық, дәстүрлері айтарлықтай өзгерістерге ұшыраған жоқ.

Түйін сөздер: туыстық қатынастар терминдері, мінез-құлық, кодексі, неке, табу, әдет-ғұрып пен дәстүрлер. 


\author{
Мулдагалиева А.А. ${ }^{1}$, Окушева Г.Т. ${ }^{2}$, Оразбекова И.Г. ${ }^{3}$, \\ ${ }^{1,2}$ К. ф.. н. Аоценты, ${ }^{3}$ К. ф.. н. \\ Казахского национального университета им. аль-Фараби, Казахстан, г. Алматы, \\ e-mail: aizhan.m@gmail.com, gulnarok.kz@gmail.com, indiragazizovna@mail.ru \\ Социокультурные функции \\ казахских терминов родства по браку
}

\begin{abstract}
В статье рассматриваются различные аспекты родства, причины возникновения системы родства и его значение для ^юдей и общества, новые теории родства, а также термины родства и кодекс поведения, который должен подАерживаться кровными родственниками и родственниками по браку. В своем историческом развитии родственные связи в человеческом обществе были мощным механизмом объединения, сотрудничества и разрешения конфликтов и напряженности, связанным с доступом к ресурсам. Запрет на инцест является неотъемлемой темой исследований родства, который также является мощным механизмом, обеспечивающим производство зАорового потомства и сохранение зАорового генофонАа. В послеАнее время изменения, происходящие в обществах, породили новую концептуализацию семей и родственных отношений. Еще одна тема, которая рассматривается в данной статье, - это система родства у казахов по браку и кодекс поведения, действующий внутри семьи, и термины, отражающие эту систему. Система терминов родства у казахов весьма разветвленная и сложная для понимания других народов, особенно термины родства по браку. Изучение этого пласта ^ексики актуально, поскольку родственные отношения в казахском обществе играют важную роль, и традиции поведения между родственниками не претерпели значительных изменений.
\end{abstract}

Ключевые слова: термины родства, кодекс поведения, брачные отношения, табу, обычаи и траАиции.

\section{Introduction}

Kinship studies have always been the topic the interest in which has never subsided (L.H. Morgan (1997), E.R. Leach (1966), B. Farber (1966), J. Middleton (1966), Bohannan P.(1968), Hareven T.K. (2000), Rapport N., Overing J. (2000), Stone L. (1997) etc.). In recent years kinship studies is undergoing a revival. Jean- Hugus Dechaux, e.g., qualifies kinship studies as a prestigious social science field (Dechaux, 2008:215).

Kinship ties are an inherent and biologically determined property of human nature, independently of its geographical and national origin. There is not a single society that does not have a relationship system. Kinship is governed by the reproduction of life. It is through kinship relations that human society ensures that human life is perpetuated and regulates the succession of generation. From the moment of his birth, a person is bornasa «relative»-son, daughter, grandson, granddaughter, nephew, niece, and only then in the course of his further life he acquires other functions in society. Each person (EGO) is in the center of the structure of kinship. At the top of the EGO in the ascending line are his mother and father and their ancestors, below in the descending line are the children of the EGO and their descendants, as well as brothers and sisters of the EGO.

\section{The importance of kinship}

Historically, for many nations, kinship has played an important role in their lives. It was one of the most effective mechanisms for adapting to the environment. It was kinship that brought unity and order into the society, ensured their harmonious coexistence and security, and formed the basis of their culture. Here there are interesting ideas concerning why and for what reasons the kinship systems have evolved and were important:

Humans depend greatly on others for access to resources, and kinship is basic to this access.

Understanding this adaptive role of kinship in human societies must employ an evolutionary perspective, that recognizes kinship behaviors and ideologies as cultural responses to ecological (resource) opportunities and constraints present in humans, given environmental and technological conditions.

Eating together has always been an important form of bonding among humans and exclusion from this activity a sign of separation. We can see that by focusing on basic principles of human behavioral ecology, by tracking social energy flow and addressing the effect of cultural constructions in creating kinship ecologies, we can begin to tie together biological and cultural evolution in an integrated way(Boyd \&Richerson, 2009:364). 
Acording to Alvard kinship systems have evolved out of necessity to solve conflicts or tensionsthat are connected with the benefits from resource access and control between the sexes and generations. Kinship norms helped to reach negotiations to peacefully solvethese issues. So kinship systems served as solutions to conflict. Conflict can contribute to breakdown in cooperation but may be minimized with organizational strategies such as kinship systems that predetermine priorities.

Cultural designation of relationships and roles with respect to rights and obligations implies that kinship acts as a powerful but complex mechanism for coordination, cooperation, and conflict resolution among humans.

Based on descent and lineage, kinship regulates the norms of family-line relationships-and even determines the rules who can marry and with whom, the guidelines for interactions between the members of the kin community and defines the proper, acceptable relationship between father and daughter, brother and sister, or husband (Alvard, 2003).

Since kinship is a «hybrid» institution involving nature and cultureitalso covers social connections, it has a wider role in society, says Puja Mondal, noting that kinship:

- Maintains unity, harmony, and cooperation among relationships;

- Sets guidelines for communication and interactions among people;

- Defines the rights and obligations of the family and marriage as well as the system of political power in rural areas or tribal societies, including among members who are not related by blood or marriage;

- Helps people better understand their relationships with each other;

- Helps people better relate to each other in society.

Kinship, then, involves the social fabric that ties families and even societies together.

The breadth of those «interlocking ties» depends on the borders of kinship ties. If kinship involves only blood and marriage ties, then it defines how family relationships form and how family members interact with one another. But if, as Schneider argued, kinship involves any number of social ties, then kinship and its rules and norms regulates how people from specific groups, or even entire communities, relate to each other in every aspect of their lives (P. Mondal, 2017).

\section{New kinship theories}

Throughout history kinship research, the natural and cultural aspects of this field have always been in the center of scholarly interest. The changes in society cannot but affect family and kinship relationships, which haveled to the emergence of new conceptualization of family and kinship. Newinvestigations on kinship demonstrate a departure from the traditional interpretation of kinship relations. Not only blood and biology can be the key components of kinship ties: the adoptive families, quasi-consanguinal kin ties through nurture and love can be the best proof of this idea.There also appeared new ideas concerning family life namely «family of choice» becauseof researchof personal lives of gay men and lesbian women. Weston drawing on the results of her research demonstrated family like quality that the members of gay and lesbian families attach to their union.

As Karsten points out, time itself has a key role in producing new meanings for kinship.Technological advancements in reproductive medicine - including sperm and egg donation, surrogacy, in vitro fertilization, cloning have ensured the revival of interest to the new conceptualization of family and growing complexity of family relationships.

It is logical that such developments have influenced the nature of kinship. Here there begs the question where does nature end and technology start? In what way do the new technologies affect our perception of kinship? One of the prevalent beliefs was that kinship is given through social intervention. Kinship ties extends far beyond the kinship groups bonded by consanguine and affinal relationships. It may bring together bigger communities who are tied together in diverse aspects of their lives (Karsten, 2004:163).

\section{Incest taboo}

The study of kinship will not be completelyfull without consideration of incest taboo and its meaning in human culture.

Historically, in societies with a tribal structure, the system of kinship was the only form of social organization and performed socially significant functions as life support, reproduction of offspring, sociolization, etc. In such societies, relationships between individuals are orderly and regulated. One of strictly observed rules in the society is an incest taboo, which has vital survival significance. In fact, incest taboo is in the heart of kinship system.

Incest is defined as sexual relations occurring between people so closely related that they are forbidden by law to marry each other.Throughout history, human societies have demonstrated an aversion towards incest. Even those living in 
societies without explicit legal systems show a negative reaction to the idea of incest. The disdain for incest exists to some degree across most human cultures, and because of this ubiquityanthropologists, psychologists, biologists, and academic researchers have studied it. An interesting fact is that incest taboo is a universal phenomenon in all societies. Most cultures have taboos, or social disapproval, against incest, and many academics suspect that this is biological and therefore a product of evolution. If something was evolved, then there must have been biological forces working towards its perpetuation. Thus, those researching the reasons for the universality of incest taboos have attempted to uncover the biological reasons for this phenomenon (Daly, Wilson, 1978).

The system itself has determined the rules governing the relationship between sexes and marital relations, preventing incest, which, according to Kazakh mentality, ensured the reproduction of healthy offspring and the preservation of a healthy gene pool. With the Kazakh society, the incest taboohas been very strictly followed and if such cases occurred, the participants were severely punished. According to a Kazakh system, incest taboo marriage between relatives is prohibited within seven generations. Therefore, the Kazakhs have developed many ways of avoiding incest. Prohibition of incest is done through different kinds of customs, codes of conduct, behavior. The Kazakh term for daughter-in-law, e.g., «kelyn» - literarily means «someone who came». There were and there still are strict expectations of the daughter-in-law's behavior. One such custom was the prohibition on the wife's using the names of her husband's relatives. She was expected to call them by other names that usually are descriptive of personal appearance or characteristics and soon popularized within the kin group. This way she established her affectionate and sisterly contact with her new relatives. Coming of an outsider to the kinship group, especially, if she had good looks, could have certain «unfavorable» consequences (Argynbaev, 1996). This was one of the ways of sex regulation among the kinship group and, in general, modest behavior is considered beneficial for a young woman.

There has always been a strict code of conduct for females, in general, and girls, in particular, had to follow. There are many proverbs, e.g. «A girl should be forbidden to go to 40 houses». There was a big responsibility on the girl, because when she married she represented her family in her husband's in-group and it was desirable that she had an irreproachable reputation so as not to disgrace her family. One of the examples of sex regulation rules is that all female cousins through both father and mother are called and any female member whom EGO calls must be treated, in all respects, as sisters, so sex relations with all sisters are therefore automatically tabooed. For Kazakhs it was and is a matter of great concern to avoid incest, to produce healthy offspring so that to improve the quality and increase the quantity of their population. (Muldagaliyeva, 2015).

\section{The importance of teaching and learning kinship terms}

Kazakh kinship system lies in the center of Kazakh culture. Most Kazakh festivals, customs and traditions are connected with family, marriage, birthdays, childbirth, etc. So teaching kinship terms to foreign students from different parts of the worldis very important because in daily communication knowingkinship terms makes communication with local people easier. Kazakh kinship terms are difficult to memorize and understand for international students. Because the Kazakh kinship terms are detailed and there are many ways of classification. Foreigners always are confused by the same kind of questions, for example, why Kazakh students sometimes call a feminine teacher by a kin term «apai» - elder sister or male teacher «ağai» - elder brother. Learning kinship terms help understand deeper and broader the Kazakh culture, the patterns of behavior, the rights and obligations of a person, the system of marriage and the way in which a person must act toward others.

\section{Terms of kinship}

Words denoting kinship, referred to as «kinship terms» in the linguistic and anthropological literature, are both an object and a means of expression of a kinship system. The system of kinship is a community of people that are related by kinship ties.

The study of kinship systems is identified with the study of kinship terms. Kinship terminology is a linguistic and logical map that, by means of a certain number of words, denotes a network of social relationships that are formed on the basis of kinship. The network of relationships is much broader than the words used to designate them. Each member of society uses this logical-linguistic map to determine his place in relation to other members within this structure. By the age of origin and the great stability of the concepts denoted by them, this thematic layer of vocabulary occupies one of the first places. 
In each culture, the terms of kinship relate to vocabulary, which historically, genetically and culturally is one of the most ancient. The establishment of kinship went in parallel with the formation and development of society. In this regard, it is impossible not to recognize the dependence of the structure-forming principles of the kinship system on real social relations. Certain social institutions find their origin in terms of kinship, which as a result can serve as a source for studying the social structure of society. Analysis of the development of kinship systems, thus sheds light on the general and particular laws of the historical evolution of society. Based on the understanding of the social conditioning of kinship terminology, they can be interpreted as a phenomenon of national culture.

Terminologically, only those relatives that are socially significant for society are distinguished. It is known that all, without exception, kinship systems have special terms for the members of the nuclear family as «the family space encompasses the atom of kinship» (Levi-Strauss, 1969).

The word family in the Kazakh language is «zhan-uja» which literally means «nest of souls».

(әке-father, шеше-mother, ana-elder sister, ciң̧iлi-younger sister (female relative), қарындас - younger sister (male relative) aza - elder brother, iнi-younger brother, еp-husband, зайblб-wife, қыз - daughter, ұл-son). It is the family space relationship within the entire kinship system that has particular significance in the life of each individual.

The relations within a family are a parent-child (әке-шеше қыз, ұл), husband-wife (er-zaib),siblingsibling (apa-singly-ini-aga-karyndas) relations.

\section{Kazakh affinal kinship}

Nanda and Warms defined marriage as the most important social institution that «refers to the customs, rules, and obligations that establish a socially endorsed relationship between adults and children and between the married couple's kin groups» (Nanda, Warms, 2006: 154).Marriage is not only an alliance between man and woman, but is alsoan alliance relationship between families, communities, descent groups and religious, political and economic groupings. Affinal kinship as well as blood kinship for the Kazakhs was and still is the strongest survival aspect. The codes of conduct is strictly observed among an affinal group because from ancient times they have evolved as a result of the pressures of survival in the harsh conditions of the life in the steppe. In this condition people had to concern themselves with the laws of the society and follow them to survive better and increase reproductive opportunities. Every member of kin group has a well-defined code of behavior patterns that ensure better adaptation to the social community and provide self-protection, mate choice, relationship maintenance, peace and solidarity in the society.Thus, affinal kinship is the type of kinship, which is based on marriage - when a husband and a wife are tied to form a nuclear family. As soon as a marriage tie is concluded, both a husband and a wife obtain new kin relatives - wife and husband's parents, siblings and many other members of their family. Levi- Strauss pointed that a kinship system of any society is merely resulted from a set of marriage rules. It represents the base of all social organizations of all societies.

Appearance of a new family means creation of social relationships between the two big communities, which consist of two nuclear families and all their relatives.

Research of affinal kinship represented by the affinal kinship terms is very important since they show the structure of this part of kinsip domain of Kazakh culture and help people and scholars of other cultural backgrounds understand the specific features of Kazakh affinal kinship system. The importance of such analysis also lies in the fact that people have an opportunity to compare and better understand their own affinal kinship system. Such analysis provide information on the affinal relations, which in Kazakh culture are considered very important and thus terminologically distinguished.

Kinship terminology is undoubtedly an excellent material for cultural linguistic studies, since the results of these studies make it possible to determine the individuality of a particular peoples' thinking about this aspect of their vital activity that may present interest to many other nations.

Affinal kinship is the type of kinship, which is based on marriage - when a husband and a wife are tied to form a nuclear family. As soon as a marriage tie is concluded, both a husband and a wife obtain new kin relatives - wife and husband's parents, siblings and many other members of their family. Levi- Strauss pointed that a kinship system of any society is merely resulted from a set of marriage rules. It represents the base of all social organizations of all societies.

Appearance of a new family means creation of social relationships between the two big 
communities, which consist of two nuclear families and all their relatives.

The act of marriage in the Kazakh language is denoted by different terms and expressions. For ex.: «turmyska shygu» (marry, literally means to start life): This term is used in relation to a female:

«kueuge shygu» (marry, literally to obtain a husband, to join a man, to become a wife of a man): this term also refers to a female.

«uilenu» (marry, lit. «to create a family heath»): the term is used in relation to a male.

«kelynshek alu» (marry, lit. «to obtain a wife»): the term refers to a male.

«nekekiu» (official act of marriage ceremony): the term refers to both male and female who after this ceremony acquire the status of a wife and husband.

Kazakh affinal terms are numerous. For comparison in the English system of kinship, there is an inlaw component, which in combination with the basic terms of kinship denotes a relative by marriage. In Kazakh kinship there are many special terms for designation of wife's and husband's parents, elder and younger brother's and sister's husbands and wives, special terms for wives of brothers in relation to each other and sister's husbands in relation to each other, parents of a husband and wife in relation to each other.

Kuyeu - husband. Besides this term in the Kazakh language, there are other words as «er - man» «bai» - lit.: «rich» which also denotes «husband».

Zaib,ayel - wife. «Ayel» means «woman». There is a word «Khatyn» also denoting «wife», which according Kazakh mentality sounds rude.

Kelynshek - wife (younger age)

$K u d a$ - fathers of husband and wife in relation to each other. It is a classificatory term, so any male of an elder age of wife' and husband's kin community is «kuda» to each other.

Kudagai - mothers of husband and wife in relation to each other.It is also a classificatory term, so any female of an elder age of wife' and husband's kin community is «kudagai» to each other.This term has a gender marker-«gai».

Kain ata - father-in-law. This term denotes «grandfather» - father and mother's father.

Ene - mother-in-law. Husband and wife's mother.

Kain aga - husband's and wife's mother. Kain is a term denoting in-law relatives.

Kain-bike - sister-in-law, husband and wife's elder sister.
Kain- singli - sister-in-law, husband's younger sister from the perspective of a wife.

Zhezde - brother-in-law, elder sister's husband from the perspective of wife's younger sister.

Abysyn - sister-in-law, brothers' wives in relation to each other.

Baldyz - sister-in-law, wife's younger sister.

Bazha - brother-in-law, sisters' husbands in relation to each other.

Kudasha - feminine relative-in-law, wife and husband's sisters, girl cousins, other female relatives from the perspective of the relatives-in-law from both sides.

Kuda-bala - male relative-in-law, wife and husband's brothers, cousins from the perspective of the relatives of both sides.

Zhesde - elder sister's or any female elder relative's husband.

\section{Results and discussion}

It should be remembered that the whole group of relatives by marriage is called «kaindar»(in-laws). This is one of the three groups of relatives that any Kazakh man/womanhas, the first group being one's own relatives, second- mother's relatives and his/ her wife's, husband's relatives.

The selection of a special term for many relatives in a marriage both from the side of the wife and from the side of the husband is due to another peculiarity of the terms of the relationship; they indicate the place of the individual in the structure of kinship, its status, defined as the social position held by the individual in a particular situation.

The status, denoted by the term kinship, personifies certain qualities, properties, rules of conduct, rights and obligations, duties in relation to another individual.

Each relative-in-law has his status among relatives-in-law and it is expected that he/she should follow the behavior pattern associated with his status and, consequently, enjoy theattitude towards him corresponding to his position on the part of others. As a rule, there are two dominating codes of conduct, which are predominantly maintained within a kinship community: respect relationship and joking relationship.

In his article «The joking relationship and kinship: charting a theoretical dependency» (Robert Parkin, 1993: 251) very scrupulously describes the nature of a joking relationship, which has a social nature since joking occurs between two persons. Although the Kazakh society, at present, is not a 
kinship, based one, kinship relations still play a significant role in people's lives and the patterns of behavior are widely observed. The joking relationship is allowed between certain relatives in the space of affinity relations. According to Radcliff-Brown (1940: 195) the «system of attitudes» functioning among kinship community as a whole is designated «to ensure group cohesion and equilibrium», maintenance of good, peaceful relations. It is commonly known, that one does not joke with freedom with any person, we do this only when we are in equivalent status - colleagues, friends, peers, so on. It is quite different in the kinship relations. With elder relatives, the joking relationship is considered unethical and impolite, although it is permitted and possible to joke if it is not a crude and rough joke, which may hurt the dignity and ruin the reputation of an elder relative.

Within the Kazakh kinship community, there are definite joking partners of opposite sex who may be potential partners in marriage. For example, man may joke with his sister-in-law (wife's younger sister) or a woman with her husband's younger brother. Husbands of sisters can also be joking partners. Of course, in real life these relatives may maintain diverse relationships but culturally joking relationship among them is not prohibited or blamed. The abundance of affinal terms in the Kazakh system indicates that kinship bonds are still important for the Kazakh society.

\section{Conclusion}

Kinship ties are an inherent and biologically determined property of human nature, independently of its geographical and national origin. Historically kinship emerged as solution to conflict and tensions regarding benefits from resource access. The changes in society cannot but affect family and kinship relationships, which have led to the emergence of new conceptualization of family and kinship. New investigations on kinship demonstrate a departure from the traditional interpretation of kinship relations. Not only blood and biology can be the key components of kinship ties: the adoptive families, quasi-consanguinal kin ties through nurture and love can be the best proof of this idea. It is also connected with the technological advancements taking place in the modern society. The conceptualization of family relationships and kinship ties are being reconsidered, especially, in the western world.

In the Kazakh society, kinship still plays a significant role in people's lives and the patterns of behavior are widely observed. Affinal kinship terminology is undoubtedly an excellent material for cultural linguistic studies, since the results of these studies make it possible to determine the individuality of a particular peoples' thinking about this aspect of their vital activity that may present interest to many other nations.

\section{References}

Abe H. (2017) Not All's Fair in Love and War: Dynasticism and Composite State Longevity in Early Modern Europe. Columbia University. Dissertation for the degree of PhD. 361 p. (In English)

Alvard M. (2003) Kinship, Lineage, and an Evolutionary Perspective on Cooperative Hunting Groups in Indonesia. // Human Nature, No. 14, pp. 129-163. (In English)

Argynbaev K. (1996) Kazakhskaya semja [Kazakh family]. Almaty, Kainar, 1996. 288 p. (in Russian). (In Russian)

Barnard A., Spencer J. (1996) Encyclopedia of Social and Cultural Anthropology. Routledge, London. 1016 p. (In English)

Bohannan P., Middleton J. (1968) Kinship and Social Organization. Natural History Press: New York. - 391 p. (In English)

Boyd R. \& Richerson P.J. (2009). Culture and the evolution of human cooperation. Philosophical Transactions of the Royal Society B, 364 (1533), 3281. Cross Ref Google Scholar. (In English)

Daly M., Wilson M. (1983) «Sex, Evolution, and Behavior ( $2^{\text {nd }}$ edition). Wadsworth Publishing Company. Belmont, California. 416 p. (In English)

Dechaux J-H. (2008) Kinship Studies: Neoclassicism and New Wave. A critical Review. Dans Revue Francaise de Sociologie. (2008/5), Vol.49, pp. 215-243. (In English)

Farber B. (1966). Kinship and Family Organization. John Wiley \&Sons. 459 p. (In English)

Farber B. (1981). Conceptions of Kinship. Elsevier, New York. 296 p. (In English)

Hareven T.K. (2000) Life-Course and Cross-Cultural Perspectives. Westview Press. 408 p. (In English)

Karsten J. After Kinship. (2004). Cambridge University Press. 216 p. (In English)

Leach E.R. (1982) Social Anthropology. Fontana, London. 222 p. (In English)

Levi-Strauss C. (1969) TheRaw and the Cooked: Introduction to a Science of Mythology. Vol. 1. London. 396 p. (In English)

Middleton J. (1968). Studies in Social and Cultural Anthropology. Crowell Marketplace, US. (In English)

Mondal P. (2017). Kinship: Brief Essay on Kinship. www.yourarticlelibrary.comsociology kinship. (In English) 
Morgan L.H. (1997) Systems of Consanguinity and Affinity of the Human Family. University of Nebraska Press, Linkoln. 604 p. (In English)

Muldagaliyeva A. A., Gumarova Sh. B., Issabayeva B. K. \& Zhirenshina K. A. (2015). The Socio-Cultural Functions of Kazakh Kinship Terms. Asian Social Science; Vol. 11, No.16. (In English)

Nanda S., Warms R.L. (2006). «Cultural Anthropology». Wadsworth Publishing (9th edition).Nanda S. \& Warms R.L. (2006). «Cultural Anthropology». 528 p. (In English)

New Directions in Anthropological Kinship. New Directions in L. Stone ed. Lanham, MD: Rowman\& Littlefield. pp. 229-245. (In English)

Parkin R. (1993). The joking relationship and kinship: charting a theoretical dependency. JASO, Vol.24, No. 3, pp. $251-263$.

(In English)

Radcliff-Brown A. (1940). On Joking Relationships.Africa: Journal of the International

African InstituteVol. 13, No. 3 (July), pp. 195-210. (In English)

RapportN., Overing J. (2000) Social and Cultural Anthropology. Routledge Press, London. 464 p. (In English)

Satubaldina A.Z. Sistemiterminovrodstva v anglijskomikazakhskomjazikah (sravnitelnijanaliz) [The system of kinship terms in

English and Kazakh languages (comparative analysis)]. https://scienceforum.ru/2015/article/2015015344 (in Russian).

Schneider D. (1980). American Kinship. Account. 2nd ed. Chicago: The University of Chicago Press Ltd. 148 p. (In English)

Stone L. (1997). Kinship and Gender: An Introduction. Westview Press. 340 p. (In English)

\section{Литература}

Morgan L.H. Systems of Consanguinity and Affinity of the Human Family. - Линкольн: University of Nebraska Press, 1997. - 604 c., Leach E.R. Social Anthropology. - Лондон: Fontana, 1982. - 222 c. Farber B. Kinship and Family Organization. - НьюЙорк:John Wiley \&Sons, 1966. - 459 с.,Farber B. Conceptions of Kinship. - Нью-Йорк: Elsevier, 1981. -296 c., Middleton J. Studies in Social and Cultural Anthropology. - Нью-Йорк: Crowell Marketplace, 1968 - 289 c.,Bohannan P., Middleton J. Kinship and Social Organization. -Нью-Йорк: Natural History Press, 2968. - 391 c., Hareven T.K. Life-Course and Cross-Cultural Perspectives. - Нью-Йорк:Westview Press, 2000. - 408 c., Rapport N., Overing J. Social and Cultural Anthropology. - Лондон:Rоutledge Press, 2000. -464 c.,

Stone L. Kinship and Gender: An Introduction. - Нью-Йорк: Westview Press, 1997. - 340 c.

Dechaux J-H. Kinship Studies: Neoclassicism and New Wave. A critical Review // Dans Revue Francaise de Sociologie. 2008/5. - T. 49. - C. 215-243.

Boyd R., Richerson P. J. Culture and the Evolution of Human Cooperation. // Philosophical Transactions of the Royal Society B, 364 (1533), 3281. CrossRefGoogle Scholar. - 2009.

Alvard M. Kinship, Lineage and an Evolutionary Perspective on Cooperative Hunting Groups in Indonesia. // Human Nature, № 14. - 2003. - C. 129-163.

Abe H.Not All's Fair in Love and War: Dynasticism and Composite State Longevity in Early Modern Europe. Колумбийскийуниверситет, диссертациянасоисканиестепени $\mathrm{PhD}, 2017 .-361$ c.

Carsten J. After Kinship. - Cambridge University Press, 2004. - C. 163.

Daly M., Wilson M. Sex, Evolution, and Behavior // Wadsworth Publishing Company. Belmont, California. - Бостон: Willard Grant Press, 1983. - 437 c.

Аргынбаев Х. Казахская семья. - Алматы: Қайнар, 1996. - 288 с.

Muldagaliyeva A. A., Gumarova Sh. B., Issabayeva B. K., Zhirenshina K. A. The Socio-Cultural Functions of Kazakh Kinship Terms // Asian Social Science;том 11, № 16. - 2015.

Levi-Strauss C. The Raw and the Cooked: Introduction to a Science of Mythology. // Том 1. - Лондон, 1969.

Nanda S., Warms R.L. «Cultural Anthropology». Wadsworth Publishing (9-йвып.), 2006. - 528 c.

Parkin R. The joking relationship and kinship: charting a theoretical dependency. JASO, Vol.24, No. 3, 1993. - c. 251-263.

Radcliff-Brown A. On Joking Relationships.Africa: Journal of the International

African Institute Vol. 13, No. 3 (July), 1940. - C. 195-210.

SatubaldinaA.Z. Системы терминов родства в английском и казахском языках (сравнительный анализ). https://scienceforum.ru/2015/article/2015015344

Schneider D. American Kinship: ACultural Account (Anthropology of Modern Societies). Вып 2-й. - Чикаго: The University of Chicago Press Ltd., 1980. - 175 c. 